\title{
The jejunal cellular infiltrate in coeliac disease complicated by lymphoma
}

\author{
R. FERGUSON, P. ASQUITH, AND W. T. COOKE ${ }^{1}$ \\ From the Department of Experimental Pathology, University of Birmingham, and \\ the Nutritional and Intestinal Unit, The General Hospital, Birmingham
}

SUMMARY Lymphocytes and plasma cells in the lamina propria and lymphocyte in the epithelium have been quantitated in jejunal biopsies from 18 patients with coeliac disease who developed lymphoma. In six patients two or more serial biopsies were available for study. Counts were compared with those obtained in 15 healthy controls and 30 other coeliacs, 15 of whom have been on a gluten-free diet for more than 12 months.

Results showed that although the lymphoma patients have abnormal counts compared with controls, they differed from untreated coeliacs in that they had lower plasma cell and higher lymphocyte counts in the lamina propria and lower lymphocyte counts in the epithelium. Such changes tended to be present for up to five years before the diagnosis of lymphoma was made. The results suggest that the immunological status of coeliac patients with lymphoma differs from that of other coeliacs and it could represent a primary abnormality and also be relevant to the development of lymphoma.

Although the malignant potential of coeliac disease, especially for lymphoma, is well recognized (Gough, Read, and Naish, 1962; Austad, 1967; Harris, Cooke, Thompson, and Waterhouse, 1967; Barry and Read, 1973), the cause remains obscure. Decreased immunological surveillance has been postulated as a factor in the causation of malignancy (Burnet, 1970). In coeliac disease, in support of such a possibility, lymphocytes show impaired PHA transformation (Holt, Ling, Winter, McCarthy, Read, and Yoffey, 1966; Blecher, BrzechwaAjdukiewicz, McCarthy, and Read, 1969; Housley, Asquith and Cooke, 1969) and altered responses in $\mathrm{EB}_{2}$ cells when cultured in vitro (MacLaurin, Cooke, and Ling, 1971). Changes in the cellular infiltrate of the jejunal mucosa may also be relevant. In contrast to the appearance of the normal mucosa, in coeliac disease there is an accumulation of lymphocytes in the epithelium (Ferguson and Murray, 1972; Fry, Seah, McMinn, and Hoffbrand, 1972) and of plasma cells in the lamina propria (Holmes, Asquith, Stokes, and Cooke, 1973), suggesting increased cellular turnover, and theoretically this might increase the risk of malignancy

${ }^{1}$ Requests for reprints should be addressed to: W.T.C., The General Hospital, Birmingham B4 6NH

Received for publication 15 March 1974. developing. Quantitation of different constituents of the cell population in coeliac patients developing lymphoma could therefore be important.

This paper reports the results of cell counts in the epithelium and lamina propria in jejunal biopsies from patients with coeliac disease who have developed histologically proven lymphoma and compares the results with those in other coeliac patients and with healthy controls.

\section{Patients and Methods}

Eighteen lymphoma patients were studied (16 reticulosarcoma of the small intestine, one peripheral Hodgkin's disease, and one peripheral lymphosarcoma) 14 of whom had been on a normal diet throughout; the remaining four patients had been on a gluten-free diet for two months, six months, nine months, and 60 months respectively. The jejunal biopsies had been obtained from patients at a mean of 2 years (range 3 months to 5 years) before the diagnosis of lymphoma was confirmed. In six of these patients two or more biopsies from each were studied. Also examined were jejunal biopsies from 15 other coeliac patients on a normal diet, 15 coeliac patients who had been on a strict gluten-free diet for more than one year, and 15 healthy controls. In six of the 18 patients with 
lymphoma, jejunal biopsies were obtained at a postmortem examination performed within one hour of death; in all other individuals peroral jejunal biopsies were obtained using the RoyChoudhury capsule (Choudhury, Nicholson, and Cooke, 1964).

Sections, $5 \mu$ thick, stained with haematoxylin and eosin, were studied with a light microscope, at a magnification of 400 . The histological field was divided into squares by placing a $1 \mathrm{~mm}$ graticule in the microscope eyepiece. Cells in each of 50 squares of lamina propria and 50 squares of epithelium were counted, and the numbers obtained were multiplied by 20 for the lamina propria and by 0.6 for the epithelium, to give the number of cells per sq $\mathrm{mm}$ of lamina propria and per $\mathrm{mm}$ length of epithelium.

The following cells were counted in the lamina propria: lymphocytes, plasma cells, and 'other cells' (reticulum cells, eosinophils, fibroblasts, and unclassified cells), the sum of these three groups constituting the total cell count. In the epithelial cell layer lymphocytes were quantitated. In the lymphoma patients where more than one biopsy was available, the most recent was used for statistical analysis. The results were compared by Student's t test.

\section{Results}

There were no significant differences in mean cell counts of 'other cells' between controls and patients with coeliac disease either before or after gluten withdrawal or between patients on a normal or a gluten-free diet. Neither was there any significant difference between the lymphoma patients and the other coeliac and control groups. These cells are not further considered.
The cell counts in the jejunal biopsies taken during life and in those taken at necropsy did not differ significantly in any respect.

Table I shows the means and standard errors of the means (SE) for total cells, plasma cells, and lymphocytes in the lamina propria and intraepithelial lymphocytes for controls, coeliacs on a normal diet and on a gluten-free diet, and coeliacs with lymphoma. The findings in six patients who had more than one biopsy before lymphoma was diagnosed are shown in table II.

\section{LAMINA PROPRIA}

\section{Total cells}

There was an increase in the mean counts in coeliac patients taking a normal diet compared with controls $(P<0.0001)$. Although patients on a gluten-free diet had lower mean counts than those on a normal diet $(P<0.0001)$, they still remained abnormal compared with controls $(P<0.0001)$. The coeliac patients with lymphoma had decreased mean cell counts compared with the two other coeliac groups $(P<0.0001)$ and increased mean counts compared with the controls $(\mathrm{P}<0.02)$.

\section{Plasma cells}

There was a marked increase in mean plasma cell counts in the lamina propria in coeliacs on a normal diet compared with normal controls $(P<0.0001)$, a reduction in coeliacs taking a gluten-free diet $(\mathrm{P}<$ $0.001)$, but not to normal levels $(P<0.001)$. The coeliacs with lymphoma had an increased number of plasmacells compared with controls $(P<0.05)$ and a decreased number compared with the coeliac patients irrespective of the latter's dietary status $(\mathrm{P}<0.001)$.

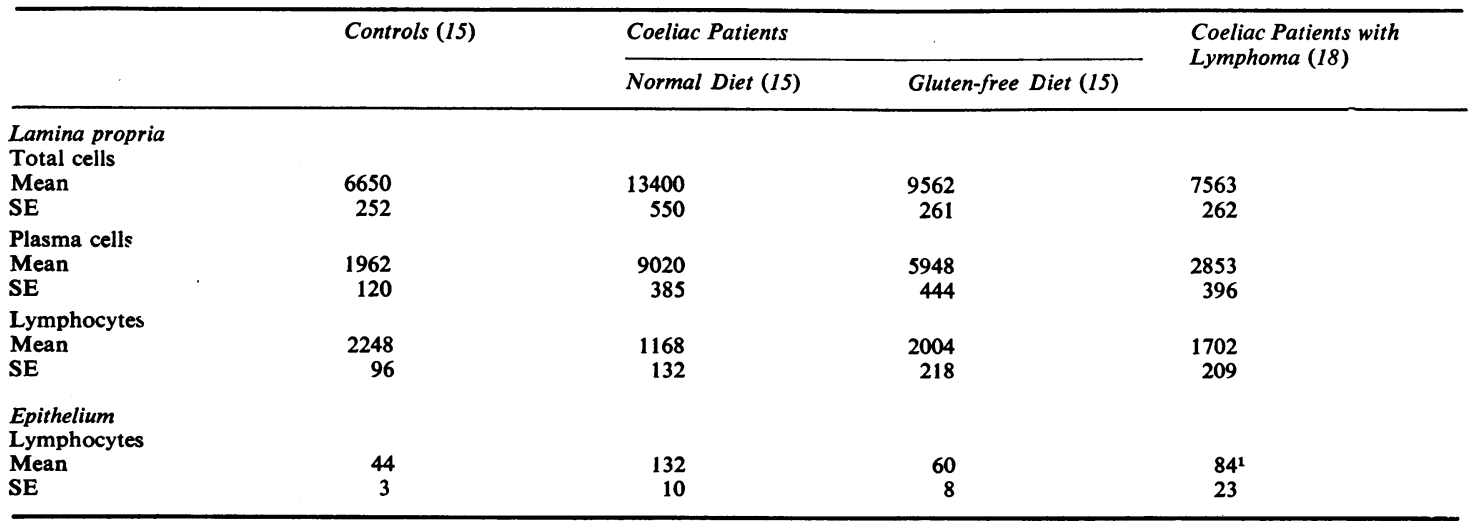

Table I Total cell, plasma cell, and lymphocyte counts in the lamina propria and lymphocytes in the epithelium of controls and of coeliac patients on either normal or gluten-free diets or coeliac patients with lymphoma

113 observations 


\begin{tabular}{|c|c|c|c|c|c|c|}
\hline \multicolumn{3}{|c|}{ Case and Date of Biopsy } & \multicolumn{3}{|c|}{ Lamina Propria } & \multirow{2}{*}{$\frac{\text { Epithelium }}{\text { Lymphocytes }}$} \\
\hline & & & Total Cells & Plasma Cells & Lymphocytes & \\
\hline $\begin{array}{l}\text { P.D. } \\
1959 \\
1963 \\
1964\end{array}$ & $\begin{array}{l}\text { (ND) } \\
\text { (ND) } \\
\text { (ND) }\end{array}$ & (malignancy diagnosed 1964) & $\begin{array}{l}5600 \\
8380 \\
5960\end{array}$ & $\begin{array}{l}3740 \\
6220 \\
3620\end{array}$ & $\begin{array}{r}500 \\
1260 \\
940\end{array}$ & $\begin{array}{l}60 \\
90 \\
84\end{array}$ \\
\hline $\begin{array}{l}\text { M.H. } \\
1968 \\
1969\end{array}$ & $\begin{array}{l}\text { (ND) } \\
\text { (ND) }\end{array}$ & (malignancy diagnosed 1969) & $\begin{array}{r}11120 \\
9160\end{array}$ & $\begin{array}{l}7780 \\
6440\end{array}$ & $\begin{array}{l}1100 \\
1040\end{array}$ & $\begin{array}{l}140 \\
142\end{array}$ \\
\hline $\begin{array}{l}\text { N.W. } \\
1960 \\
1964\end{array}$ & $\begin{array}{l}\text { (ND) } \\
\text { (ND) }\end{array}$ & (malignancy diagnosed 1966) & $\begin{array}{l}7360 \\
9740\end{array}$ & $\begin{array}{l}3980 \\
6100\end{array}$ & $\begin{array}{l}1160 \\
1420\end{array}$ & $\begin{array}{l}88 \\
48\end{array}$ \\
\hline $\begin{array}{l}\text { C.B. } \\
1969 \\
1970 \\
1971\end{array}$ & $\begin{array}{l}\text { (ND) } \\
\text { (GFD) } \\
\text { (GFD) }\end{array}$ & (malignancy diagnosed 1972) & $\begin{array}{l}9760 \\
9120 \\
8060\end{array}$ & $\begin{array}{l}4000 \\
2060 \\
3400\end{array}$ & $\begin{array}{l}2040 \\
2960 \\
2080\end{array}$ & $\begin{array}{l}70 \\
-\end{array}$ \\
\hline $\begin{array}{l}\text { M.B. } \\
1971 \\
1972\end{array}$ & $\begin{array}{l}\text { (ND) } \\
\text { (GFD) }\end{array}$ & (malignancy diagnosed 1972) & $\begin{array}{l}7660 \\
5320\end{array}$ & $\begin{array}{l}1720 \\
1620\end{array}$ & $\begin{array}{r}2320 \\
820\end{array}$ & $\begin{array}{r}60 \\
140\end{array}$ \\
\hline
\end{tabular}

Table II Total cell, plasma cell, and lymphocyte counts in the lamina propria and lymphocyte counts in the epithelium of six patients with jejunal biopsies on one or more occasions before the diagnosis of lymphoma

${ }^{1}$ Normal diet $\quad{ }^{2}$ Gluten-free diet $\quad-=$ Not counted

\section{Lymphocytes}

In coeliacs on a normal diet, the mean number of these cells were lower than the controls $(P<0.00001)$. There was a rise in the group on a gluten-free diet $(P<0.004)$, and these counts did not differ significantly from normal. In the lymphoma group the mean count fell in between the other groups of coeliacs, differing significantly from coeliacs on a normal diet $(P<0.001)$ but not from that of those on a gluten-free diet and was also lower than that of the controls $(P<0.03)$.

\section{EPITHELIUM}

\section{Lymphocytes}

Coeliacs on a normal diet had higher mean counts than controls $(P<0.0001)$. Coeliacs on a gluten-free diet had lower counts than those on a normal diet $(P<0.0001)$, and their counts, though higher than those of controls, were not significantly different. The mean number of cells in the lymphoma coeliacs fell in between the other two coeliacs groups differing significantly from coeliacs on a normal diet $(P<$ 0.004), but not from those on a gluten-free diet, and was higher than that of controls $(P<0.003)$.

Table II shows that the changes in the counts of total cells, plasma cells, and lymphocytes in the lamina propria and lymphocytes in the epithelial cell layer that were found in the lymphoma group tended to be present in biopsies counted up to five years before the diagnosis of lymphoma.

\section{Discussion}

Biopsies of the jejunal mucosa from patients with coeliac disease on a normal diet have increased numbers of total cells and plasma cells but a decreased lymphocyte population in the lamina propria and increased numbers of lymphocytes in the epithelium. The changes are less marked in the coeliacs on a gluten-free diet. In lymphoma the findings were unexpected. The lymphocyte counts for the lamina propria and the epithelium resembled the findings in coeliacs on a gluten-free diet, despite the fact that 14 of the lymphoma coeliacs were on a normal diet. Far more striking were the plasma cell counts which were significantly lower than in either group of coeliacs. The changes in plasma cell counts largely accounted for the difference in total cell counts.

From dog experiments (Vaerman and Heremans, 1970 ) it is apparent that a proportion of systemic IgA is produced in the jejunal mucosa. In coeliac patients developing lymphoma a rise in serum IgA has been noted (Asquith, Thompson, and Cooke, 1969), and, if immunological mechanisms in man are similar to those of dog, a proportion of this should be formed in the jejunal mucosa. Hence, in lym- 
phoma patients one might have predicted an increase in lamina propria plasma cells. In fact, relatively low plasma cell counts were found. It is possible that a specific increase in IgA cells occurred but this was not reflected in total plasma cell counts because of a decrease in other classes of immunoglobulin-producing cells. To elucidate this point a study of plasma cells using fluorescent-labelled specific antisera to the $\alpha, \mu, \gamma, \delta$, and $\epsilon$ heavy chains would be necessary.

The relatively low lamina propria cell counts may be important in other respects. In uncomplicated coeliac patients the low lymphocyte counts in the presence of increased plasma cells could be explained if gluten provided an antigenic stimulus to the lymphocytes resulting in their transformation to antibody-producing plasma cells. This is known to occur in other situations (Roitt, 1971). In lymphoma patients fewer plasma cells might arise if this transformation did not occur but instead stimulated lymphocytes formed malignant clones. Such 'cell deviation' seems more likely in the presence of reduced immunological surveillance (Schwartz, 1972), which, on the basis of other evidence, is thought to be present in coeliac disease (MacClaurin et al, 1971). The relatively low lymphocyte counts in the epithelial layer compared with those found in uncomplicated coeliacs could be pertinent to this point. Intraepithelial lymphocytes are known to consist of $T$ and $B$ lymphocytes (Ferguson and Parrott, 1972), hence the low lymphocyte counts may represent a specific loss of $T$ cells which are known to be especially concerned in immunological surveillance (Lancet, 1973).

Finally, it is possible that the changes in plasma cells and lymphocytes in patients with lymphoma compared with other coeliacs are a primary abnormality. The changes occurring in six patients up to several years before the development of the lymphoma makes this suggestion possible. Consequently, low plasma cell and intraepithelial lym- phocyte counts might help to indicate which coeliac patients are prone to develop malignancy.

R.F. is in receipt of a grant from the Endowment Fund of the United Birmingham Hospitals.

\section{References}

Asquith, P., Thompson, R. A., and Cooke, W. T. (1969). Serum immunoglobulins in adult coeliac disease. Lancet, 2, 129-131.

Austad, W. I., Cornes, J. S., Gough, K. R., McCarthy, C. F., and Read, A. E. (1967). Steatorrhoea and malignant lymphoma. Amer. J. dig. Res., 12, 475-490.

Barry, R. E., and Read, A. E. (1973). Coeliac disease and malignancy. Quart. J. Med., 42, 665-675.

Blecher, T. E., Brzechwa-Ajdukiewicz, A., McCarthy, C. F., and Read, A. E. (1969). Serum immunoglobulins and lymphocyte transformation studies in coeliac disease. Gut, 10, 57-62.

Burnet, F. M. (1970). The concept of immunological surveillance. Progr. exp. Tumour Res., 13, 1-27.

Choudhury, D. C. R., Nicholson, G. I., and Cooke, W. T. (1964). Simple capsule for multiple intestinal biopsy specimens. Lancet, 2, 185-186.

Ferguson, A., and Murray, D. (1971). Quantitation of intraepithelial lymphocytes in human jejunum. Gut, 12, 988-994.

Ferguson, A., and Parrott, D. M. V. (1972). The effect of antigen deprivation on thymus dependent and thymus independent lymphocytes in the small intestine of the mouse. Clin. exp. Immunol., 12, 477-488.

Fry, L., Seah, P. P., McMin, R. M. H., and Hoffbrand, A. V. (1972). Lymphocytic infiltration of epithelium in diagnosis of gluten sensitive enteropathy. Brit. med. J., 3, 371-374.

Gough, K. R., Read, A. E., and Naish, J. M. (1962). Intestinal reticulosis as a complication of idiopathic steatorrhoea. Gut, 3, 232-239.

Harris, O. D., Cooke, W. T., Thompson, H., and Waterhouse, J. A.H. (1967). Malignancy in adult coeliac disease and idiopathic steatorrhoea. Amer. J. Med., 42, 899-912.

Holmes, G. K. T., Asquith, P., Stokes, P. L., and Cooke, W. T. (1973.) Cellular infiltrate of jejunal biopsies in adult coeliac disease (A.C.D.) in relation to gluten withdrawal. (Abstr.) Gut, 14, 429.

Holt, P. J., Ling, N. R., Winter, G. C. B., McCarthy, C. F., Read, A. E., and Yoffey, J. M. (1966). Responses to phytohaemaglutinin. Lancet, 1, 980-981.

Housley, J., Asquith, P., and Cooke, W. T. (1969). Immune response to gluten in adult coeliac disease. Brit. med. J., 2, 159-161.

Lancet (1973). The lymphocyte. Editorial. Lancet, 1, 409-410.

MacLaurin, B. P., Cooke, W. T., and Ling, M. R. (1971). Impaired lymphocyte reactivity against tumour cells in patients with coeliac disease. Gut, 12, 794-800.

Roitt, I. M. (1971). The significance of immunoglobulin determinants on the lymphocyte surface. Int. Arch. Allergy appl. Immunol. 41, 96-97.

Schwartz, R. S. (1972). Immunoregulation oncogenic viruses and malignant lymphomas. Lancet, 1, 1266-1269.

Vaerman, J. P., and Heremans, J. F. (1970). Origin and molecular size of Immunoglobulin-A in the mesenteric lymph of the dog. Immunology, 18, 27-38. 